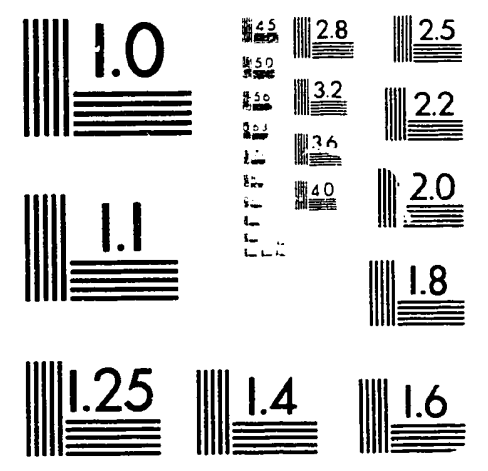



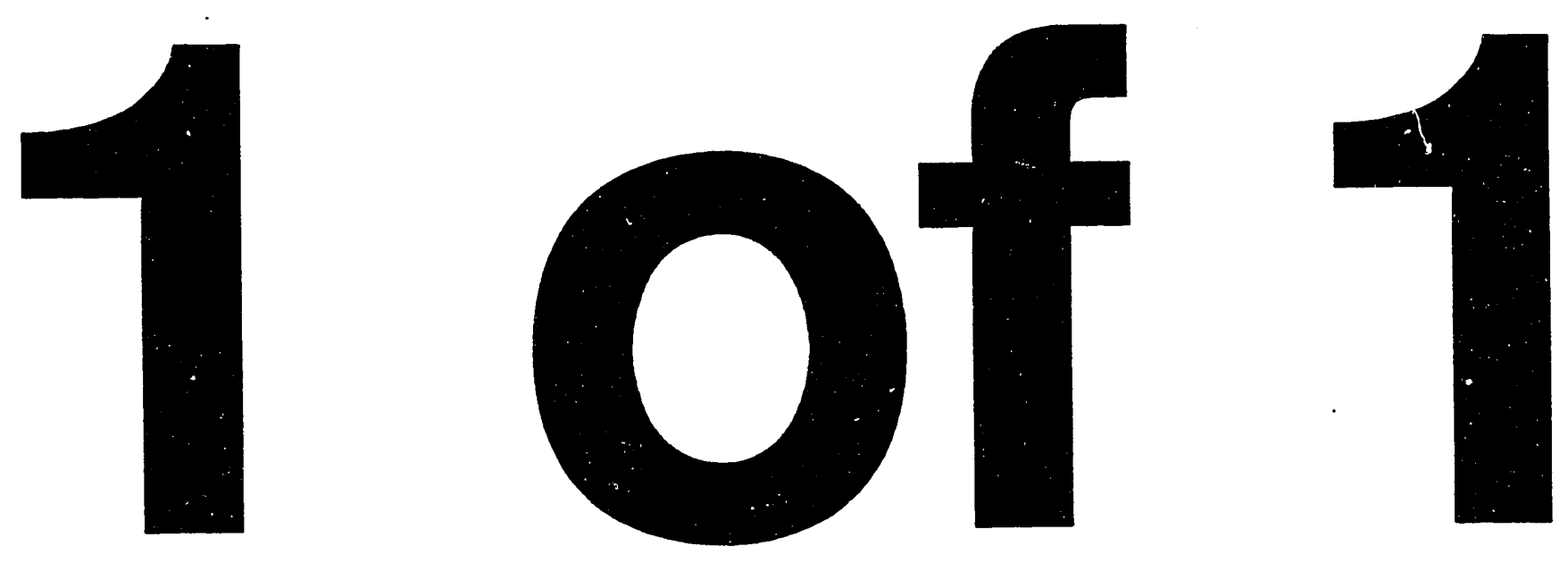


\title{
ALTERNATIVES FOR SODIUM-POTASSIUM ALLOY TREATMENT
}

\author{
T. J. Takacs \\ M. E. Johnson \\ Chemistry and Chemical Engineering Department \\ Development Division
}

Date of Issue: April 8, 1993

\author{
Prepared by the \\ Oak Ridge Y-12 Plant \\ Oak Ridge, Tennessee 37831 \\ managed by \\ Martin Marietta Energy Systems, Inc. \\ for the \\ U.S. DEPARTMENT OF ENERGY \\ under contract DE-AC05-84OR21400
}




\section{TABLE OF CONTENTS}

LIST OF FIGURES............................................................................................................................4

LIST OF TABLES...................................................................................................................................................

SUMMARY......................................................................................................................................5

INTRODUCTION ....................................................................................................................................6

BACKGROUND .............................................................................................................................7

PRESENTATION OF EXPERIMENTAL WORK …............................................................................8

PROCESS DESCRIPTIONS...............................................................................................................

EXPERIMENTAL SETUP .............................................................................................................8

THE CAUSTIC PROCESS..................................................................................................................10

THE PROPYLENE GLYCOL PROCESS...................................................................................11

DISCUSSION OF RESULTS............................................................................................................................16

THE CAUSTIC PROCESS............................................................................................................16

THE PROPYLENE GLYCOL PROCESS.....................................................................................16

COMP/RISON OF PROCESSES...............................................................................................19

COST ESTIMATE...............................................................................................................20

CONCLUSIONS AND RECOMMENDATIONS................................................................................21

REFERENCES.......................................................................................................................................................22

A: PROJECT SIZING COST STUDY.............................................................................................................23 


\section{FIGURES}

Figure

\section{Page}

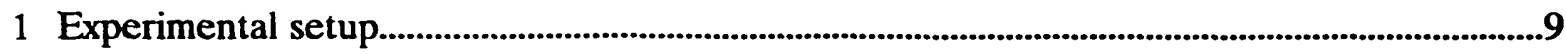

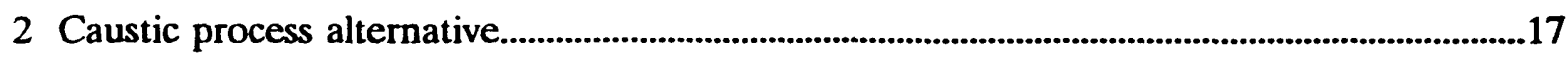

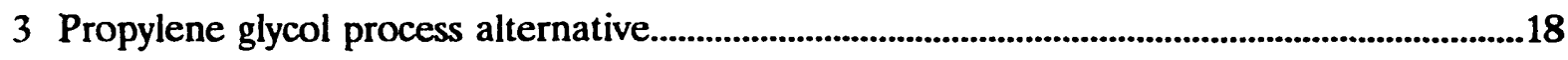

\section{TABLES}

Table

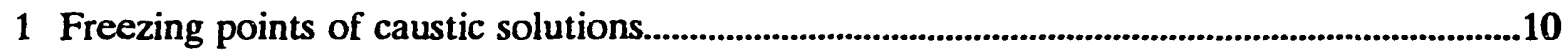

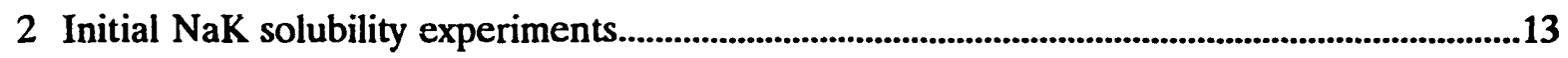

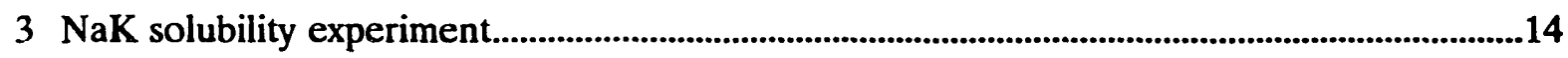

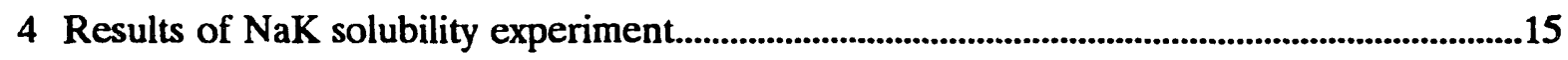

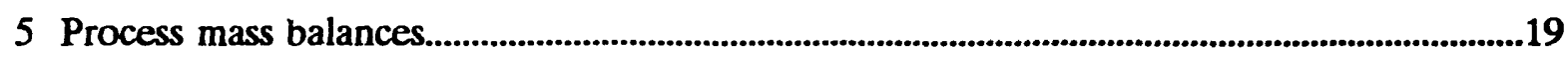




\section{SUMMARY}

Sodium-potassium alloy (NaK) is currently treated at the Y-12 Plant by open burning. Due to uncertainties with future permits for this process, alternative treatment methods were investigated, revealing that two treatment processes are feasible.

One process reacts the $\mathrm{NaK}$ with water in a highly concentrated molten caustic solution (sodium and potassium hydroxide). The final waste is caustic that may be used elsewhere in the plant. This process has two safety concerns. Hot corrosive materials used throughout the process present handling difficulties. Also, the process must be carefully controlled (temperature and water content) to avoid explosive $\mathrm{NaK}$ reactions.

To avoid these problems, a second process was developed that dissolves $\mathrm{NaK}$ in a mixture of propylene glycol and water at room temperature. While this process is safer, it generates more waste than the caustic process. However, the waste may possibly be used as a carbon food source in biological waste treatment operations at the Y-12 Plant.

Experiments were conducted to demonstrate both processes, and they showed that both processes are feasible alternatives for $\mathrm{NaK}$ treatment. Process flow sheets with mass balances were generated for both processes and compared. While the caustic process generates less waste, the propylene glycol process is safer in several ways (temperature, material handing, and reaction control). The authors recommend that the propylene glycol alternative be pursued further as an alternative for $\mathrm{NaK}$ treatment.

In order to optimize this process for a larger scale, several experiments should be conducted. The amount of $\mathrm{NaK}$ dissolved in propylene glycol and subsequent waste generated should be optimized. The offgas processes should be optimized. The viability of using this waste as a carbon food source at one of the Y-12 Plant treatment facilities should be investigated. Finally, if the state accepts this process as an alternative, design and construction of a pilot-scale treatment system should begin. 


\section{INTRODUCTION}

Sodium-potassium alloy $(\mathrm{NaK})$ is used as a coolant in a skull caster furnace at the Y-12 Plant. The furnace is scheduled to be shut down by the end of 1993, leaving $\sim 250$ gal of NaK for treatment. In the past, $\mathrm{NaK}$ has been treated by open burning; however, the permit with the state of Tennessee expires in November 1993 and will not allow for the treatment of the total NaK waste. The Y-12 Plant Development Division has been asked to develop a low-cost, small scale treatment alternative. This project was planned to have two phases. The first phase was to demonstrate the feasibility of treatment alternatives. The second phase was to demonstrate and optimize the process on a pilot scale. This report documents the results of the first phase. The information gathered from this investigation will be used to compare other alternatives. Also, it may be used in negotiations with state authorities to extend the open burning permit. 


\section{BACKGROUND}

$\mathrm{NaK}$ is a silver-colored liquid metal alloy used as a coolant in a skull caster furnace at the Y-12 Plant. Similar to liquid sodium, $\mathrm{NaK}$ is very reactive with oxygen, water, and hydrocarbons. For example, when contacted with water, $\mathrm{NaK}$ reacts instantly, creating sparks, flames, splattering, and/or explosions (depending on the reaction conditions). Hydrogen gas, which is also quite flammable, evolves from the reaction. $\mathrm{NaK}$ is also harmful when contacted with skin. Typically, $\mathrm{NaK}$ is handled under an inert atmosphere, such as nitrogen or argon, and is stored under a layer of mineral oil to prevent reactions.

By the end of 1993, the skull caster furnace, which is the only source of $\mathrm{NaK}$ waste, should be out of service. At this time, $\sim 250 \mathrm{gal}$ of $\mathrm{NaK}$ will have to be treated. The current treatment process is open-air burning. The permit for this process from the Tennessee Department of Environment and Conservation (TDEC) will expire in November 1993. The permit only allows for the burning of a total of $20 \mathrm{gal}$ of $\mathrm{NaK}$ (for the entire life of the permit). Unless a request to the state to allow open burning for the rest of the NaK is successful, an alternate treatment method is needed. Waste Management asked the Y-12 Plant Development Division to develop a process that would be safe and cost effective for the required amount of $\mathrm{NaK}$. 


\section{PRESENTATION OF EXPERIMENTAL WORK}

\section{PROCESS DESCRIPTIONS}

Two similar processes were developed and evaluated simultaneously. The first process reacts NaK (78\% potassium by weight) with water using sodium and potassium hydroxide as a diluent to minimize the hazards of the reaction. The reaction is as follows:

$$
\mathrm{NaK}_{2}(\mathrm{l})+3 \mathrm{H}_{2} \mathrm{O}(\mathrm{l}) \rightarrow 2 \mathrm{KOH}(\mathrm{l})+1 \mathrm{NaOH}(\mathrm{l})+3 / 2 \mathrm{H}_{2}(\mathrm{~g}) \uparrow .
$$

(Althnugh $\mathrm{NaK}_{2}$ is the correct formula for the alloy, it is commonly referred to as "NaK". In this report, "NaK" will be ured except in chemical equations.)

The final products of this reaction are caustic $(\mathrm{KOH}$ and $\mathrm{NaOH})$, which may be recycled through the process, and hydrogen. Due to the relatively high concentration of caustic used and produced ( 70 to $80 \mathrm{wt} \%$ caustic), the reactants and products must be heated to maintain fluidity. The molten corrosive solutions and explosive hydrogen gas are the chief hazards of this process.

The second process uses propylene glycol as a reactant/diluent. Like water and most alcohols, propylene glycol also reacts with $\mathrm{NaK}$, but at a more controllable rate. In this process, hydrogen gas is generated in the same quantities as in the caustic process. The final liquid product is a relatively safe-to-handle inixture of propylene glycol and caustic, which could possibly be used as a food source in the bioreactors of the Y-12 Plant.

\section{EXPERIMENTAL SETUP}

Initially, the processes were tested in beaker scoping studies, which varied in size and purpose and will be discussed in detail in later sections. To tesi both processes on a larger scale under an iriert atmosphere, the setup shown in Figure 1 was used. Propylene glycol is shown in the figure, but caustic may be used as well.

The setup consisted of a 1-L glass reactor with mixing from an overhead mixer. The process was designed to safely control the amount of $N, K$, fed to the reaction vessel. The desired amount of $\mathrm{NaK}$ (usually less ther $5 \mathrm{~mL}$ ) was fed with argon from its storage container to a glass separator funnel. After the feed line from the storage container was closed, the NaK was added drop by drop, with argon, from the separator funnel to the reaction vessel.

The funnel contained 5 to $10 \mathrm{~mL}$ of mineral oil or propylene glycol to help feed the NaK, depending on the nature of the experiment. Mineral oil, rather than propylene glycol, is commonly used in NaK storage and containment. Because mineral oil is lighter and insoluble in water, it tended to surround the $\mathrm{NaK}$ in the reactor, creating an unreactive emulsion. Propylene glycol did not have this problem. However, propylene glycol is heavier than and mildly reactive with $\mathrm{NaK}$, creating clogging problems when feeding. On a larger scale, feeding $\mathrm{NaK}$ is not a problem. Such a process would use a gravity feed of $\mathrm{NaK}$ in greater quantities with relatively small amounts of mineral oil (from storage).

Argon was used to maintain an inert atmosphere and to feed the NaK. The argon also purged the hydrogen gas created during the reaction. The exiting purge line was fed through a bubbler (about $100 \mathrm{~mL}$ of water, propylene glycol, or mineral oil in a 250-mL Erlenmeyer flask) to dissolve any vaporized caustic or organic. The setup also sately dissipated hydrogen into the hood. 


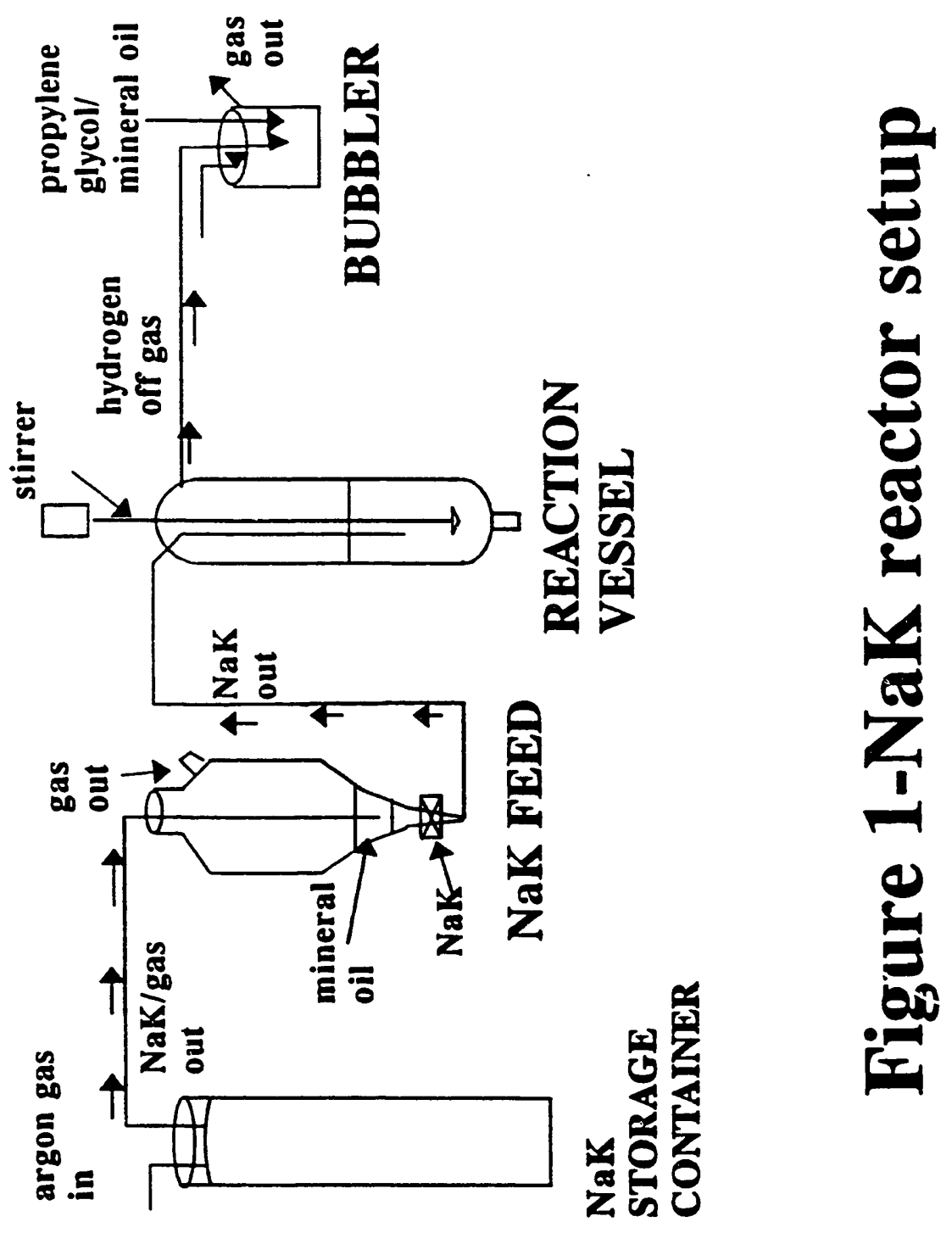


Before experiments began, a Health and Safety Readiness Review was conducted to independently evaluate the safety of this setup. The process was approved, with the caution that the development of this project beyond this laboratory scale should be closely followed. If and when the experimental configuration is appreciably altered or expanded, another review will be required. In addition to this, a safety evaluation for the process was conducted by the Development Compliance Assistance Group, which was approved by Facility Safety.

\section{THE CAUSTIC PROCESS}

In the caustic process, regulation of the reaction requires about 70 wt $\%$ caustic. As the caustic concentration increases, the reaction is milder because of dilution of the reactants. At high concentrations, the caustic is solid at room temperature and must be heated or diluted with additional water. As the NaK reacts, the caustic concentration increases and heat evolves. As a result, the operating temperatures are usially well above $90^{\circ} \mathrm{C}$. NaK becomes spontaneously combustiole at $115^{\circ} \mathrm{C}$ under a normal atmosphere; therefore, even under an inert atmosphere, temperatures were usually kept below this level. Experiments concentrated on finding a feasible caustic concentration and temperature for this process.

Initial beaker experiments were conducted to find a workable caustic concentration. One hundred grams of solid caustic ( $78 \mathrm{~g}$ of $\mathrm{KOH}$ and $22 \mathrm{~g}$ of $\mathrm{NaOH}$ ) were measured into a glass beaker with $10 \mathrm{~g}$ of water. The mixture was heated until it was completely liquid at $140^{\circ} \mathrm{C}$ and then cooled until crystals formed at $120^{\circ} \mathrm{C}$. Ten more grams of water were added and the process was repeated. The process continued over a range of concentrations and temperatures, as shown in Table 1.

Table 1. Freezing points of caustic solutions

\begin{tabular}{|c|c|c|c|c|}
\hline $\begin{array}{c}\text { Total } \\
\text { Weight } \\
(\mathrm{g})\end{array}$ & $\begin{array}{c}\text { Water } \\
\text { Weight } \\
(\mathrm{g})\end{array}$ & $\%$ Water & $\begin{array}{c}\text { Temperature } \\
\text { Completely } \\
\text { Fluid }\left({ }^{\circ} \mathrm{C}\right)\end{array}$ & $\begin{array}{c}\text { Freezing } \\
\text { Point } \\
\left({ }^{\circ} \mathrm{C}\right)\end{array}$ \\
\hline \hline 110 & 10 & 9.1 & 140 & 120 \\
\hline 120 & 20 & 16.5 & 130 & 105 \\
\hline 130 & 30 & 23.1 & 110 & 80 \\
\hline 135 & 35 & 25.9 & 90 & 60 \\
\hline
\end{tabular}

Another beaker experiment (in a hood under normal atmospheric conditions) was performed with $20 \mathrm{wt} \%$ water in caustic. One hundred grams of caustic and $25 \mathrm{~g}$ of water were measured into a 1-L thick-walled glass beaker. The stirred mixture was heated until the caustic was liquid at $130^{\circ} \mathrm{C}$ then cooled until crystals formed at $116^{\circ} \mathrm{C}$. The molten caustic was again heated to $125^{\circ} \mathrm{C}$. To observe the reaction above the temperature at which NaK becomes combustible, a small drop of NaK was added. The NaK immediately reacted, creating shooting sparks and a small flame. Ten grams of water were added (to make $26 \mathrm{wt} \%$ water) and the temperature was lowered to $97^{\circ} \mathrm{C}$. Small drops of $\mathrm{NaK}$ were added again, creating sparks. The reaction was slightly less vigorous than the first reaction but still hazardous. The solution was then transferred to a $100-\mathrm{mL}$ beaker. A drop of $\mathrm{NaK}$ with a dark (presumably oxide) coating was added. After a noticeable delay $(\sim 30 \mathrm{~s})$, the corting dissipated. When the drop became, shiny, it caught fire and 
emitted sparks. These experiments established $23 \mathrm{wt} \%$ water as a lower water concentration limit and emphasized the necessity of depleting oxygen from the system. With the absence of oxygen, the NaK becomes far less reactive and hazardous.

The system was then tested on a larger scale with the system shown in Figure 1. Initially, a stoichiometric mix of $\mathrm{KOH}$ and $\mathrm{NaOH}$ with $25 \mathrm{wt} \%$ water $(184 \mathrm{~g}$ of $\mathrm{NaOH}, 516 \mathrm{~g}$ of $\mathrm{KOH}$, and $300 \mathrm{~g}$ of water) was added to the reactor. The mixture was heated with an electric heating mantle to above $120^{\circ} \mathrm{C}$ to completely liquify the solution then cooled to $110^{\circ} \mathrm{C}$. The heating mantle was then removed to observe the $\mathrm{NaK}$ addition more clearly. At $106^{\circ} \mathrm{C}, 0.5 \mathrm{~mL}$ of $\mathrm{NaK}$ was fed to the reactor with $8 \mathrm{~mL}$ of propylene glycol. The reaction created a great amount of smoke that filled the reactor and turned the solution light brown. The color and smoke were believed to be due to the presence of propylene glycol. These results were not seen during the beaker caustic studies. No sparks, flames, or sigrificant temperature increases were observed. Successive additions of $1 \mathrm{~mL}$, then $2 \mathrm{~mL}$ of $\mathrm{NaK}$, each with $5 \mathrm{~mL}$ of propylene glycol, followed. The temperature for these additions were $103^{\circ} \mathrm{C}$ and $93^{\circ} \mathrm{C}$, respectively. Again, except for a great deal of smoke, no hazardous effects were observed. At this point, the experiment was halted because the NaK feed line became clogged.

These experiments demonstrated the basic feasibility of the caustic process. However, because of its inherent hazards, especially caustic handling and high temperatures, work focused on the propylene glycol process.

\section{THE PROPYLENE GLYCOL PROCESS}

During a literature review, the authors discovered that one method for treatment of very small quantities of $\mathrm{NaK}$ is by reaction with and dissolution in alcohol. ${ }^{1}$ Alcohol has also been used in the nuclear industry for the safe cleaning of sodium-wetted reactors and components. ${ }^{2}$ The general reaction is

$$
\mathrm{NaK}_{2}(\mathrm{l})+3 \mathrm{ROH}(\mathrm{l}) \rightarrow 2 \mathrm{~K}^{+} \mathrm{RO}^{-}(\mathrm{l})+\mathrm{Na}^{+} \mathrm{RO}^{-}(\mathrm{l})+3 / 2 \mathrm{H}_{2}(\mathrm{~g}) \dagger
$$

This reaction is very similar to the water based reaction, with an organic group (R) replacing one of water's hydrogen atoms. The rate for alcohols is considerably slower than that for water. In general, the heavier the organic group, the slower the reaction. The $\mathrm{K}^{+} \mathrm{RO}^{-}$and $\mathrm{Na}^{+} \mathrm{RO}^{-}$ compounds are referred to as potassium and sodium alcoholates. Studies were begun to find an alcohol that reacted safely with the $\mathrm{NaK}$ at room temperature and produced an acceptable waste product.

Because of to their availability, first beaker scoping studies were done with methanol $\left(\mathrm{CH}_{3} \mathrm{OH}\right)$ and isopropanol $\left(\mathrm{C}_{3} \mathrm{H}_{7} \mathrm{OH}\right)$. $\mathrm{NaK}$ was added drop by drop to $10 \mathrm{~mL}$ of the chosen alcohol in a 1-L glass beaker at room temperature in an open hood. As expected, methanol was more reactive than isopropanol. The $\mathrm{NaK}$ dissolved in about $30 \mathrm{~s}$ in methanol and in $5 \mathrm{~min}$ in isopropanol. No sparks or flames were observed. Due to the mildness of the reaction, water was added to observe its effect. Experiments were conducted with $100-\mathrm{mL}$ solutions of both alcohols in 0 to $90 \mathrm{vol} \%$ water. As expected, reactivity increased as the water concentration increased. At higher water concentrations, sparks and flames formed on the surface of the solution. Also, the reactivity (and sparks) increased dramatically with stirring.

Although these experiments were successful in finding a less reactive solvent, several concerns were raised. Most alcohols, including the preceding two, are flammable. Using them in a process that may generate sparks and flames is risky. Also, the alcoholates are very alkaline organic salts. 
Solution $\mathrm{pH}$ from the beaker experiments reached 13.6 , even when relatively small portions of $\mathrm{NaK}$ were reacted. Although the Y-12 Plant treatment facilities could possibly handle such wastes, secondary waste treatment is not yet determined for either process. At this point, investigations turned to propylene glycol.

Propylene glycol $\left(\mathrm{CH}_{3} \mathrm{CHOHCH}_{2} \mathrm{OH}\right)$ is a dihydric alcohol with two potentially reactive hydruxyl groups on two separate carbons. It is nonflammable (flash point of $210^{\circ} \mathrm{F}$ ). Propylene glycol is used at the Y-12 Plant both as a machining coolant and as a carbon food source for biodenitrification at the West End Treatment Facility (WETF). Although thorough investigations should be conducted, an alkaline solution of propylene glycol (below $40 \mathrm{wt} \%$ in water) can potentially be consumed by the microorganisms at WETF.

Beaker experiments in an open hood were conducted to qualitatively determine the reactivity of propylene glycol with NaK. Solutions with 10, 20, 30, 40, 50, and $100 \mathrm{vol} \%$ propylene glycol in water were prepared. One hundred milliliters of each solution were measured into $250-\mathrm{mL}$ beakers, and NaK was added drop by drop without mixing. Small sparks and a flame were observed as $\mathrm{NaK}$ dissoived instantly in the $10 \%$ solution. From 20 to $40 \%$, only singular small sparks were observed as the $\mathrm{NaK}$ was added. In these solutions, $\mathrm{NaK}$ dissolved slowly with noticeable fizzing. For the $50 \%$ and $100 \%$ solutions, no flames or sparks occurred, even when the solutions were mixed. The NaK eventually dissolved after several minutes.

Experiments continued under an argon atmosphere with the same setup as was used with caustic process (Figure 1). The main objective of the experiments was to determine the solubility oi the $\mathrm{NaK}$ in propylene glycol/water solutions. From experimental data with methanol and sodium metal $^{3}, 12$ wt \% of $\mathrm{NaK}$ was expected to dissolve in the solution.

One liter of $50 \mathrm{vol} \%$ propylene glycol (in water) was measured into the reactor. NaK was added drop by drop with $100 \%$ propylene glycol (used to flush the NaK through the lines). The solution was mixed constantly and the temperature monitored. Table 2 shows the addition amounts, temperatures, and observations. It also shows the approximate wt \% of sodium and potassium ions in the final solution, assuming that all of the sodium and potassium remained in the reactor and that none vaporized. At the end of this experiment the bubbler solution remained clear, indicating that no sodium or potassium had been entrained in the offgas. The experiment was interrupted when the authors observed the undissolved $\mathrm{NaK}$ in the reactor.

To examine the solution more closely, a 70-mL sample was pulled from the bottom. It had a light-brown tint and a $\mathrm{pH}$ of 13.6. A small amount of undissolved $\mathrm{NaK}$ appeared to be trapped in oil (probably mineral oil residue from earlier experiments).

To dissolve the NaK, the reactor, with the remaining solution, was heated. At $77^{\circ} \mathrm{C}$, the $\mathrm{NaK}$ still did not dissolve. To drain the reactor for cleaning, $500 \mathrm{~mL}$ were pulled from the bottom, which caused the $\mathrm{NaK}$ on the surface to smoke and dissolve, probably the result of air pulled into the reactor as it was drained. The $500-\mathrm{mL}$ solution appeared to be free of oil or undissolved $\mathrm{NaK}$, so it was saved for further experiments.

After this experiment, the reactor was cleaned to remove any oily residue. The $500-\mathrm{mL}$ solution was returned to the reactor, and $\mathrm{NaK}$ was once again added under an argon atmosphere. The addition amounts and observations are shown in Table 3.

The final solution was very dark brown (almost black) yet still clear, without any visible suspended solids. The calculated concentration of sodium and potassium ions was $3.46 \mathrm{wt} \%(\sim 4.2 \mathrm{vol} \%$ ). The water in the bubbler had a light-brown tint, indicating that some of the solution had 
Table 2. Initial NaK solubility experiment

\begin{tabular}{|c|c|c|c|c|c|}
\hline $\begin{array}{l}\text { Vol. of } \\
\text { NaK added } \\
(\mathrm{mL})\end{array}$ & $\begin{array}{l}\text { Vol of } \\
\text { propylene } \\
\text { glycol } \\
\text { added with } \\
\text { NaK (mL) }\end{array}$ & $\begin{array}{l}\text { Initial } \\
\text { Temp } \\
\left({ }^{\circ} \mathrm{C}\right)\end{array}$ & $\begin{array}{l}\text { Max. } \\
\text { Temp. } \\
\text { after NaK } \\
\text { added }\end{array}$ & $\begin{array}{l}\text { Wt \% of } \\
\mathrm{Na}^{+} \& \mathrm{~K}^{+} \\
\text {ions }\end{array}$ & Observations \\
\hline 0.2 & 10 & 22.2 & 22.4 & 0.01 & $\begin{array}{l}\text { Instant dissolution } \\
\text { of } \mathrm{NaK} \text {, no sparks } \\
\text { or flames }\end{array}$ \\
\hline 0.2 & 5 & 22.3 & 22.3 & 0.03 & Same \\
\hline 0.5 & 8 & & 22.6 & 0.07 & $\begin{array}{l}\text { Tan tint to } \\
\text { solution }\end{array}$ \\
\hline 0.6 & 8 & 22.4 & 24.1 & 0.12 & $\begin{array}{l}\text { Lots of smoke; } \\
\text { dissipated after } \\
\sim 1 \text { min. }\end{array}$ \\
\hline 1 & 10 & 23.9 & 23.8 & 0.20 & Same \\
\hline 2 & 10 & & 24.7 & 0.36 & $\begin{array}{l}\text { Did not dissolve } \\
\text { as readily }\end{array}$ \\
\hline 1.5 & 15 & & 25.6 & 0.47 & Same \\
\hline 4 & 10 & & 24.9 & 0.77 & $\begin{array}{l}\text { Undissolved NaK } \\
\text { observed on the } \\
\text { surface }\end{array}$ \\
\hline
\end{tabular}


Table 3. NaK solubility experiment

\begin{tabular}{|c|c|c|c|}
\hline $\begin{array}{l}\text { Volume of NaK } \\
\text { (ml) }\end{array}$ & $\begin{array}{l}\text { Volume of } \\
\text { propylene glycol } \\
\text { added with NaK } \\
\text { (ml) }\end{array}$ & $\begin{array}{l}\text { Wt \% of } \\
\mathrm{Na}^{+} \& \mathrm{~K}^{+} \\
\quad \text { ions }\end{array}$ & Observations \\
\hline 0 & 0 & 0.77 & $\begin{array}{l}\text { Solution from end of experiment } \\
\text { described in Table } 2\end{array}$ \\
\hline 1 & 5 & 0.90 & Reacts quickly; no sparks or flames \\
\hline $\mathbf{0}$ & 2 & 0.89 & $\begin{array}{l}\text { Propylene glycol only to flush residual } \\
\text { NaK from lines }\end{array}$ \\
\hline 2 & 6 & 1.20 & Some NaK splattered on sides of reactor \\
\hline 0 & 5 & 1.19 & Propylene glycol flush \\
\hline 2 & 5 & 1.49 & Reacts quickly; brown tint to solution \\
\hline 0 & 3 & 1.48 & Propylene glycol flush \\
\hline 3 & 5 & 1.93 & Reacts fine; Temp $-26^{\circ} \mathrm{C}$ \\
\hline 4 & 5 & 2.50 & $\begin{array}{l}\text { Temp }-29.1^{\circ} \mathrm{C} \text {; Lots of smoke; } \\
\text { Backpressure almost pulls water from } \\
\text { bubbler into reactor; Increase argon flow } \\
\text { to correct problem }\end{array}$ \\
\hline 3 & 5 & 2.92 & Temp - $31.2^{\circ} \mathrm{F} ;$ No problems \\
\hline 4 & 5 & 3.47 & $\begin{array}{l}\text { Temp }-32.8^{\circ} \mathrm{C} \text {; Some NaK splattered in } \\
\text { reactor; single spark was observed. }\end{array}$ \\
\hline 0 & 1 & 3.46 & Propylene glycol flush \\
\hline
\end{tabular}

vaporized (or had been entrained in the hydrogen offgas) and dissolved in the bubbler. The assumption that all of the sodium and potassium remained in the bubbler was not valid for this experiment. For this reason, the calculated wt \% of sodium and potassium ions in solution was higher than actual value. One hundred milliliters of this solution and the water solution used in the bubbler were analyzed for sodium and potassium concentration and organic content. A blank solution of $50 \%$ propylene glycol in water was analyzed at the same time. The results, shown in Table 4, were used as the basis for the process flow sheet (see "Discussion of Results").

The remaining solution ( $466 \mathrm{~mL}$ ) was used to determine if more NaK could be dissolved. In the reactor under argon, a total of $8 \mathrm{~mL}$ of $\mathrm{NaK}$ was added in 3 approximately equal portions (with $\sim 20 \mathrm{~mL}$ propylene glycol). During the first addition, the temperature rose from room temperature to $40.6^{\circ} \mathrm{C}$. During the second addition, a spark was observed and the temperature rose suddenly to $49^{\circ} \mathrm{C}$. The solution was allowed to cool to $34.4^{\circ} \mathrm{C}$ before the third addition. After the third addition, the temperature increased again to $49^{\circ} \mathrm{C}$. At this point the total concentration of sodium and potassium ions in solution was, at most, $3.8 \mathrm{wt} \%$. This experiment demonstrates the increasing hazards as the solution became concentrated. 
Table 4. Results of NaK solubility experiment

\begin{tabular}{||l|l|l|l||}
\hline & $\begin{array}{l}50 \% \text { Prop. } \\
\text { Glycol Soln }\end{array}$ & Final Solution & $\begin{array}{l}\text { Bubbler } \\
\text { Solution }\end{array}$ \\
\hline Potassium Conc. $(\mathrm{mg} / \mathrm{L})$ & $<30$ & $>10000$ & 4300 \\
\hline Sodium Conc. $(\mathrm{mg} / \mathrm{L})$ & $<30$ & 9530 & 614 \\
\hline Total Organic Carbon $(\mathrm{mg} / \mathrm{L})$ & 303000 & 36000 & 1100 \\
\hline
\end{tabular}

The authors conducted several beaker experiments in an open hood to try to reach a maximum concentration of $\mathrm{NaK}$ in propylene glycol. They also investigated the effect of varying propylene glycol concentration. Although these experiments are cruder than those with the reactor, they required less time and material. These experiments could be done in smaller volumes, requiring less $\mathrm{NaK}$ to reach saturation. One hundred milliliters of 40,60 , and $80 \mathrm{vol} \%$ propylene glycol solutions were measured into 600 - $\mathrm{mL}$ beakers. NaK was added drop by drop with a pipet. A plastic dish with a hole was used to cover the beakers to contain sparking and splattering. Because the great amount of offgas was not contained and the final product was usually solid at room temperature, the final waste concentrations were difficult to approximate or measure. The results from these experiments are only qualitative.

During the test with the 40 vol \% solution, $\mathrm{NaK}$ was added very slowly, $0.5 \mathrm{~mL}$ to $1 \mathrm{~mL}$ at a time. A total of $50 \mathrm{~mL}$ of $\mathrm{NaK}$ were added. After 5 to $6 \mathrm{~mL}$ of $\mathrm{NaK}$ were added, the solution was expected to turn dark brown; however, it became light brown but did not grow very dark until the last $10 \mathrm{~mL}$ were added. Excessive smoke was generated during the experiment. The temperature was not measured during the $\mathrm{NaK}$ addition. After all $50 \mathrm{~mL}$ were added, the temperature was $117^{\circ} \mathrm{C}$. The final volume was $\sim 50 \mathrm{~mL}$. As the solution cooled, it quickly solidified.

The 60 vol \% solution behaved similarly. After $18.4 \mathrm{~mL}$ of $\mathrm{NaK}$ had been added, the solution was dark brown and cloudy and looked very similar to the final $40 \mathrm{vol} \%$ solution. At this point, the temperature was $175^{\circ} \mathrm{C}$. After $34 \mathrm{~mL}$ of $\mathrm{NaK}$ had been added, the solution was very viscous and the NaK took considerably longer to react. After a total of $40 \mathrm{~mL}$ of $\mathrm{NaK}$ had been added, the solution sustained a flame for an abnormally long time (over $30 \mathrm{~s}$ ). The final solution was black, viscous, and oily and solidified upon returning to room temperature.

The 80 vol \% solution was unexpectedly reactive. In earlier beaker studies, as propylene glycol concentration increased, reactivity decreased, but not for this case. The first $3 \mathrm{~mL}$ were added quickly, creating flames and turning the solution very dark brown. As the experiment continued, the NaK for some unknown reason was more reactive with the solution than with the two earlier solutions. After $19 \mathrm{~mL}$ had been added, the volume of the solution was slightly less than $100 \mathrm{~mL}$ and the temperature was $54^{\circ} \mathrm{F}$. After $2 \mathrm{~mL}$ more were added, the $\mathrm{NaK}$ stopped reacting and formed a nonreactive layer on the surface. The NaK appeared to be trapped in an emulsion, yet no oil had been added to the solution. The maximum solubility of $\mathrm{NaK}$ appeared to have been reached for this concentration of propylene glycol. More experiments should be done to understand $\mathrm{NaK}$ dissolution in higher concentrations (if this information is deemed necessary). 


\section{DISCUSSION OF RESULTS}

Both processes are feasible for a larger scale. Although the systems differs in operating parameters and final waste forms, both processes are very similar. A selection should be based on a close comparison of the two.

Two flow sheets were developed to compare processes and evaluate costs. The basis for both flow sheets was the treatment of $5 \mathrm{gal}$ of $\mathrm{NaK}$ in $4 \mathrm{~h}$. This scale was selected to compare with the current open burn permit which allows for burning of 5 gal of NaK "at a time", a phrase that is loosely defined.

\section{THE CAUSTIC PROCESS}

Figure 2 shows the caustic process flow sheet. The preceding experiments were used as a basis, assuming a final water concentration of $30 \mathrm{wt} \%$. The heat of reaction shown was calculated from tabulated values ${ }^{4}$, assuming that the $\mathrm{NaK}$ reacts solely with water. (Theoretically, the $\mathrm{NaK}$ will react with the caustic but generally at much higher temperatures.) Another assumption is that little caustic is vaporized in the reactor and that all that is vaporized is dissolved in the bubbler.

The initial caustic solution is $260 \mathrm{~kg}$ of caustic, $35 \%$ water. The final waste, including the bubbler sclution, is a total of $358 \mathrm{~kg}$ of caustic, $46 \%$ water. Assuming that the waste is not too contaminated with other materials, $198 \mathrm{~kg}$ may be used in the $\mathrm{NaK}$ dissolving tank and added to $62 \mathrm{~kg}$ of fresh caustic to continue the process. The rest of the waste $(160 \mathrm{~kg})$ should be relatively clean caustic that may be used in waste treatment operations. The relatively small amount of waste is the greatest benefit of this process; however, the largest drawback is safety. Throughout the process, hot corrosive materials must be handled, requiring careful execution of the process and special equipment (heated tanks, steam-traced lines, etc.). The temperature and amount of water in contact with the $\mathrm{NaK}$ must also be carefully controlled to prevent explosive reactions.

\section{THE PROPYLENE GLYCOL PROCESS}

Figure 3 shows the flow sheet for the propylene glycol process. The final waste from the reactor is $341 \mathrm{~L}$ of $60 \mathrm{wt} \%$ propylene glycol [360,000 ppm total organic carbon (TOC)] with $34,280 \mathrm{ppm}$ potassium, and $9530 \mathrm{ppm}$ sodium. The bubbler waste, as shown, has the composition of $4300 \mathrm{ppm}$ potassium, $614 \mathrm{ppm}$ sodium, and $1100 \mathrm{ppm}$ TOC ( $\sim 0.2 \%$ propylene glycol). These compositions were found from the data in Table 4 and a subsequent mass balance for potassium. The mass balance calculations were based on the following assumptions.

1. The amount of undissolved NaK described in Table 2 was negligible when compared with the overall amount of $\mathrm{NaK}$ dissolved.

2. The bubbler solution used for additions in Table 4 had a final volume of $100 \mathrm{~mL}$, which is a good estimate that has little effect on the overall mass balance.

3. All of the vaporized material dissolved in the bubbler (a good assumption based on observations).

This composition is not necessarily optimal. As demonstrated in beaker experiments, the waste could be more concentrated. However, as the waste becomes concentrated, it becomes more combustible and viscous. As the dissolved $\mathrm{NaK}$ concentration increases, the waste becomes a solid (at room temperature), alkaline substance that has the same handling difficulties associated 


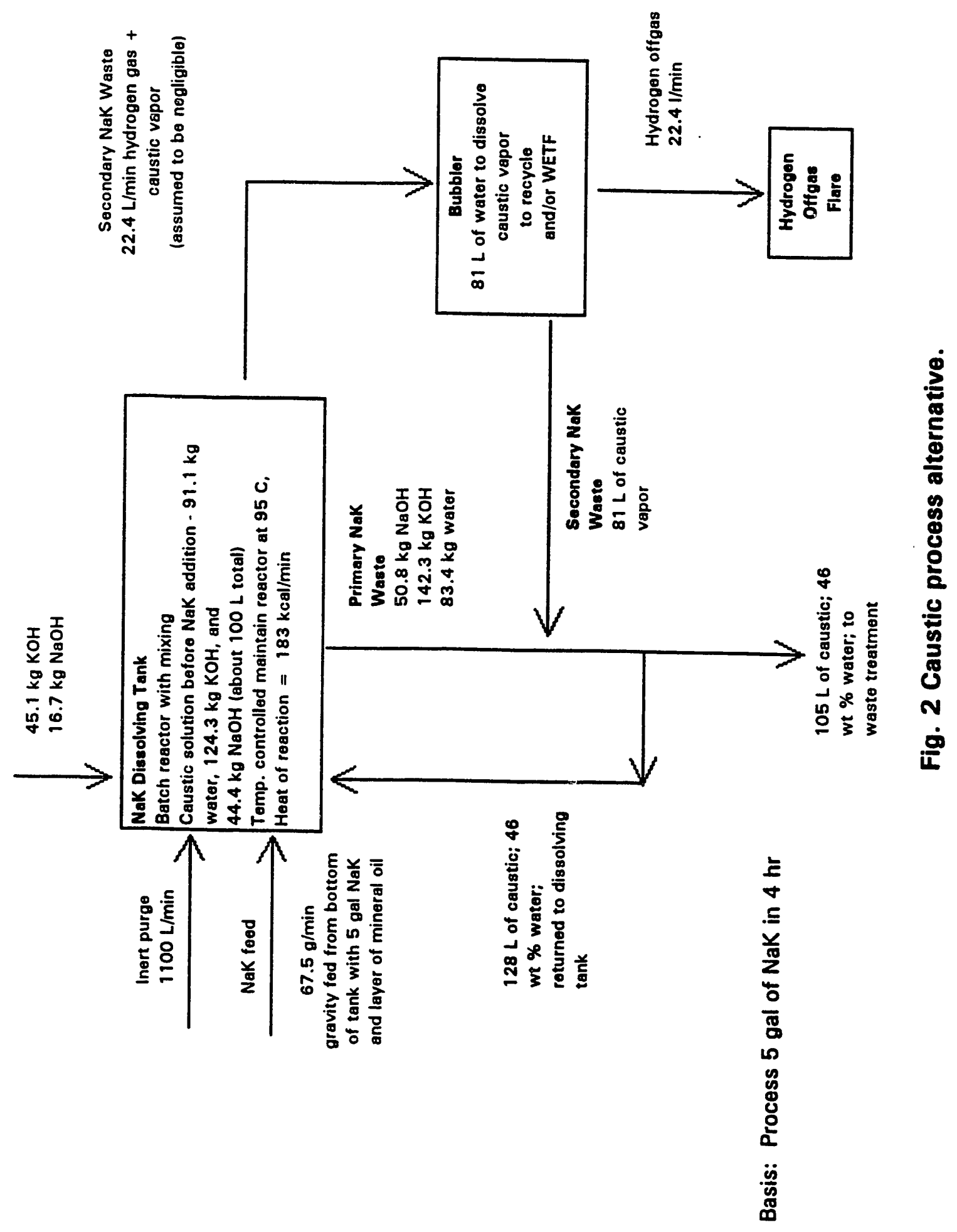




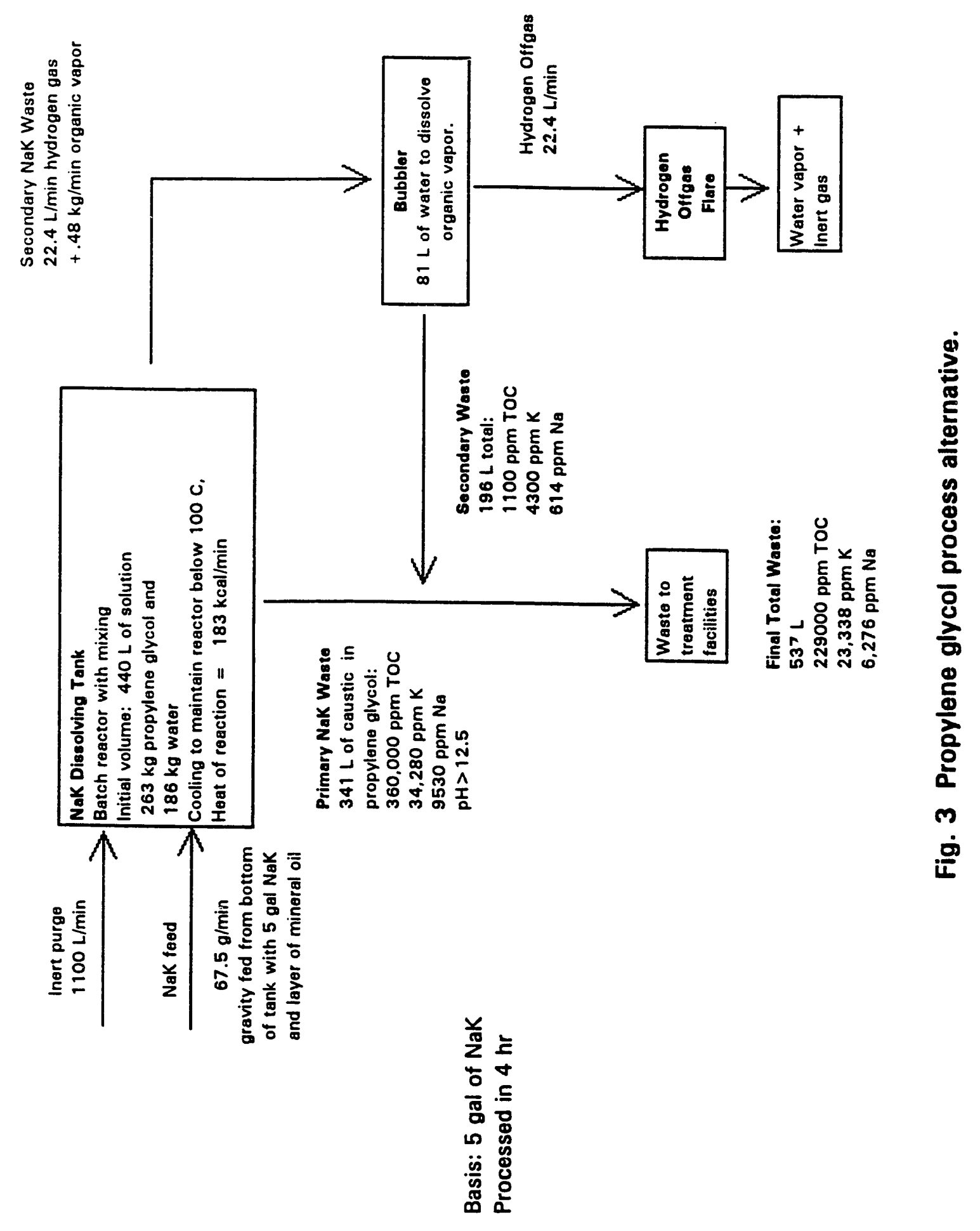


with the caustic process; therefore, the endpoint represented by the composition noted was chosen.

The waste from this process is an organic caustic solution. This waste may likely be used as a food source in the Y-12 Plant waste treatment facilities. Before being added to a bioreactor, the waste should be neutralized to reduce $\mathrm{pH}$ effects and diluted to less than $25 \%$ propylene glycol. Above this con entration, propylene glycol is toxic to microorganisms, but below this concentration it is an excellent food source. A second concern is that the waste might raise sodium discharge levels from the treatment facility. High discharge concentrations of sodium can create toxicity problems. Because $\mathrm{NaK}$ is $23 \mathrm{wt} \%$ sodium, any waste generated from any process will have sodium. As shown in the flow sheet, the total amount generated from this process is about 7000 gal with $6300 \mathrm{ppm}$ sodium over 10 weeks or longer. This relatively small amount will be diluted to reduce the propylene glycol concentration and further mixed with other wastes. Because of this dilution, the sodium discharge level should not be adversely affected.

The heat from the reaction of water with $\mathrm{NaK}$ is used on this flow sheet. It is a worst case value. $\mathrm{NaK}$ may actually react with water, propylene glycol, or both. From theory and observation of $\mathrm{NaK}$ reactions separately with water and propylene glycol, one would think that $\mathrm{NaK}$ reacted solely with water. The reaction rate for $\mathrm{NaK}$-water reacticn is generally higher than that of alcohols. The heat of reaction (calculated from tabulated heats of formation ${ }^{5}$ ) for the water reaction is also higher: $276 \mathrm{kcal} / \mathrm{mol}$ for water reaction vs $122 \mathrm{kcal} / \mathrm{mol}$ for propylene glycol reaction. These calculated values are consistent with those determined experimentally for NaK reaction with water and methanol ${ }^{6}$. However, the experiments conducted with propylene glycol/water mixtures indicate that some of the $\mathrm{NaK}$ reacted with the glycol. The brownish color that was observed indicates sodium and potassium ions that would not be present in a mixture of sodium and potassium hydroxides and propylene glycol.

\section{COMPARISON OF PROCESSES}

As was shown earlier, the two processes were demorstrated to be feasible. Table 5 shows a comparison of the mass balances of the processes. In many respects, the processes are alike. Both react $\mathrm{NaK}$ with water, which is somehow diluted, in a controlled manner under an inert atmosphere. Both generate at the same rate hydrogen offgas which must be handled carefully.

Table 5. Process mass balances

\begin{tabular}{||l|l|l||}
\hline & Caustic Process & Propylene Glycol Process \\
\hline $\begin{array}{l}\text { Basis: amount of NaK } \\
\text { treated }\end{array}$ & 5 gal $(16.3 \mathrm{~kg})$ & 5 gal $(16.3 \mathrm{~kg})$ \\
\hline Amount of waste generated & 105 liters $(158 \mathrm{~kg})$ & 537 liters $(548 \mathrm{~kg})$ \\
\hline Composition of waste & $46 \mathrm{wt} \%$ water & $\begin{array}{l}38 \mathrm{wt} \% \text { propylene glycol } \\
23,338 \mathrm{ppm} \mathrm{K} \\
6,276 \mathrm{ppm} \mathrm{Na}\end{array}$ \\
& $14 \mathrm{wt} \% \mathrm{NaOH}$ & $22.4 \mathrm{~L} / \mathrm{min}$ \\
\hline
\end{tabular}


The differences are waste generated and operating temperature. As shown in the process flow sheets, the propylene glycol will produce approximately 5 times more waste than the caustic process. In this comparison, it is important to note that this will not be an on-going process. Only a limited amount of $\mathrm{NaK}(\sim 250 \mathrm{gal})$ will be treated. When compared with the overall amount of aqueous waste generated at the Y-12 Plant, the difference in waste generated is insignificant. To maintain fluidity, the caustic process must be kept above $90^{\circ} \mathrm{C}$. As a result, het caustic solutions must be managed carefully. Special safety precautions, as well as heated tanks and piping, are required. The propylene glycol process may be operated at room temperature with fewer safety precautions; therefore, it is the preferred process.

\section{COST ESTIMATE}

Y-12 Plant Engineering made a rough cost estimate of the cost of the propylene glycol process for use in discussions of alternatives with TDEC. This estimate was made quickly with limited cost information from vendors and engineering experience. It was assumed that the treatment facility would be built from scratch and not from existing facilities. In actuality, either existing facilities or a temporary structure will be used, which would lower construction and overhead. The total project cost was $\$ 363,030$. The actual equipment cost was $\$ 90,000$. The project sizing cost study is included in the appendix. 


\section{CONCLUSIONS AND RECOMMENDATION'S}

Two alternative processes for $\mathrm{NaK}$ treatment were shown to be feasible. The caustic process generates less waste overall but has serious safety concerns. Temperature, water concentration, and caustic handling must be carefully controlled throughout the process. Hot corrosive material used and generated in the process must be managed carefully. The propylene glycol process operates at room temperature and is considerably safer than the caustic process. It does produce more waste, but this amount is insignificant when compared with overall Y-12 Plant waste generation. The authors recommend that this process ie pursued as a likely alternative for NaK treatment.

Work should be done to optimize this process on a larger scale. Experiments should be conducted to optimize the amount and composition of the final waste. The feasibility of using this waste as a carbon food source in biological treatment should be studied. The offgas processes (bubbler and flare) need to be further investigated and optimized (to reduce the waste generated). Also, the use of nitrogen, a less expensive inert gas than argon, should be investigated. Finally, depending on the State's position on NaK treatment, design and construction of a pilot unit should begin. 


\section{REFERENCES}

1. Carey B. Jackson, ed., Liquid Metals Handbook, Sodium (NaK) Supplement Atomic Energy Commission and the Bureau of Ships, Department of the Navy, 1955, p. 12.

2. E. H. Voice, "The Reaction of Sodium Metal with Alcohol", Liquid Metal Engineering and Technology, Vol. 2, Proceedings of the Third International Conference held at Oxford on April 9-13, 1984, The British Nuclear Energy Society, London, 1984, pp. 157-163.

3. E. H. Voice, "The Reaction of Sodium Metal with Alcohol", Liquid Metal Engineering and Technology, Vol. 2, Proceedings of the Third International Conference held at Oxford on April 9-13, 1984, The British Nuclear Energy Society, London, 1984.

4. O. J. Foust, ed., Sodium-NaK Engineering Handbook, Vol. 1, Sodium Chemistry and Physical Properties, Gordon and Breach, Science Publishers, Inc., New York, 1972, p. 250.

5. Robert C. Weast, ed., CRC Handbook of Chemistry and Physics, 60th ed., CRC Press, 1979, pp. D67-D77.

6. E. H. Voice, "The Reaction of Sodium Metal with Alcohol", Liquid Metal Engineering and Technology, Vol. 2, Proceedings of the Third International Conference held at Oxford on April 9-13, 1984, The British Nuclear Energy Society, London, 1984. 


\section{PROJECT STING COST STUTY}

Project Name: NaK DISPOSAL-PROPYLNE GLYCOL ALTERNATIVE' jategory: NONE

STIE: Y-12; SOURCE : Y-12

$$
\text { Extimator: Jerry Rem }
$$

SteP 1. COST DRIVERS

SEE ASSUMPTIONS AND SCOPE OF WORK ASEE PAGE 2

TOTAL COST DATVEAS

Step 2. CONSTRUCTION COST FACTORS

7.1 Mob. a Demob., Shop Support. Clean up

7.2 Heoth Pryices

7.4 Training / Salety

7.5 Material Tax

Subtotal Cost Factore

Suhrotal Direct Construction

7.6 Consuruetion Indirecoss

7.7 MuEs Overtiond

Total Fiedd Consuration

7.3 MKF Seleried Field Support

7.7 Max-F Consturuedon Managernort

subtotal

7.8 MMES Overtread

Subtotal.MKF-F

TOTAL CONSTRUCTON

Step 3. TITE I I DESTEN

8.1 MMES Oventued on AEE Deaign

STEP 4 MMES SUPPOFT FACTORS

9.1 Tithe if Exoinceating

9.2 AVE Support

9.3 Conuturetion Support

9.4 Sretume Enginentirs

9.5 FFA Compliance

9.6 Mavies Oventoad

SUBTOTAL

Subtoral Low Contingancy

Step 8. Contmisencr

TOTAL PROJECT COST who additonal escalation

Step 6. Escalation borond time of Cost Ditver

Step 7. TOTAL PROJECT COST with additional eseatation

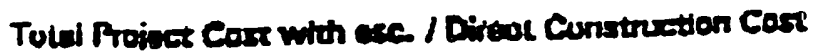

800.000

$\begin{array}{ll}\text { Rude of } & \text { Totd } \\ \text { Thumb, } x & \text { Add - On }\end{array}$

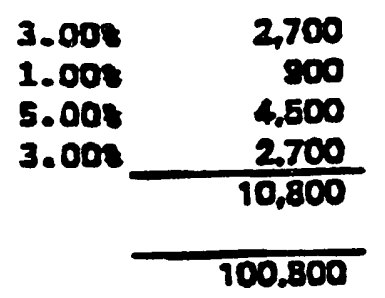

\begin{tabular}{rr}
26.008 & 28.208 \\
e.71\% & 8.522 \\
\hline 135.530
\end{tabular}

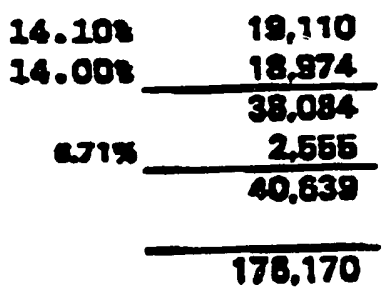

\begin{tabular}{rr}
16.008 & 28,187 \\
$0.71 \%$ & 1.891 \\
\hline 30,079
\end{tabular}

\begin{tabular}{rr}
10.008 & 17.817 \\
6.005 & 10.570 \\
6.005 & 10.670 \\
0.000 & 0 \\
5.008 & 8.808 \\
31.704 & 18.097 \\
\hline & \\
\hline & \\
\hline
\end{tabular}

$23.008 \frac{07,228}{338.130}$

$8.002 \quad 28,891$

363.030 
Arsunprons

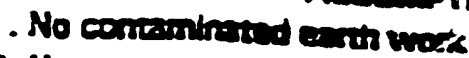

2. No uruserd entroumburat conditions

3. Project corrinuetion completion FY 9414

4. Projece is expesue tunded

5. Duration of ditopeal projeces ts 50 doys
Descruption
1. 2074x100Z GRAVE RaADs

2. $20^{\circ} \times 40^{\circ} \times 6^{\circ}$ COMVEITIE PNO

3. $300 \mathrm{LF}$ of SECUITY FaICE MND CATIS

4. STE TRANER FOR 3 MONTHS

5. 1000 Gal Amtioci=s TANi

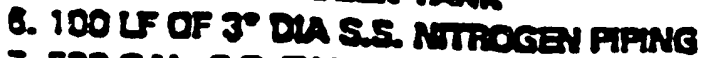

7. 500 GNL \&S TANT, VAVVE, ETC.

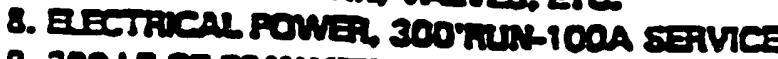

9. 300 LF of 2 wATE Une VALVES. ETC

10. DEerofuntTons STATIOH

11. 100 LF OF 10 EN ES. FiFE ND FTJWNGS

12. BUBBLEA STATIOU

13.HYOROGEU CFFAS FLAR 5TATION

14. 800 cAl FoRY TAWK

16. PEMOVAL OF EOMUPME:T

15. Mist MATEzLLLS
TOTAL

DOLAFT

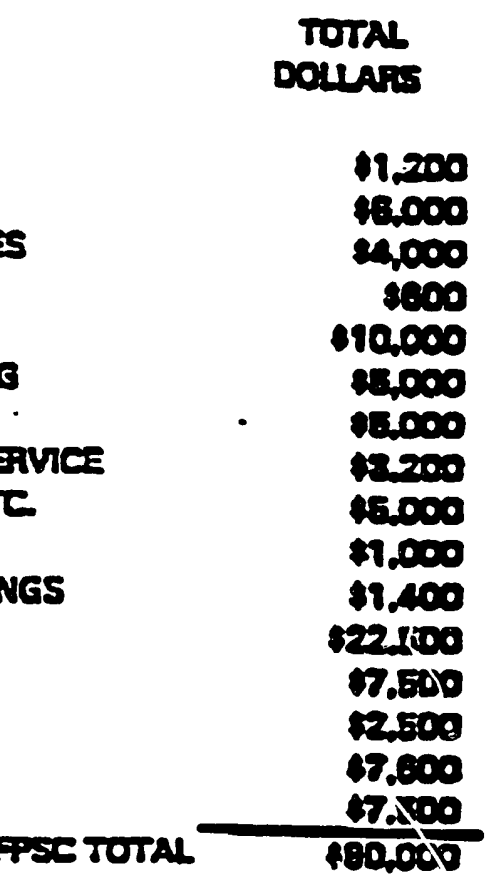

Fixed price jub wht 
Distribution

M. L. Baker

K. D. Delius

H. L. Fellers

J. E. Heiskell/J. E. Sto. 1e

W. P. Huxtable

I. W. Jeter

M. E. Johnson (3)

A. K Lee/DOE-OSTI

D. K. Little

J. K. Prazniak

G. L. Seeber

I. D. Shelton

C. M. Smith

W. E. Smith

T. J. Takacs (3)

H. A. Valentine

Y. R. Weaver

A. D. Wood

ETG Document Center

Y-12 Central Files (RC)

9202 File Point 

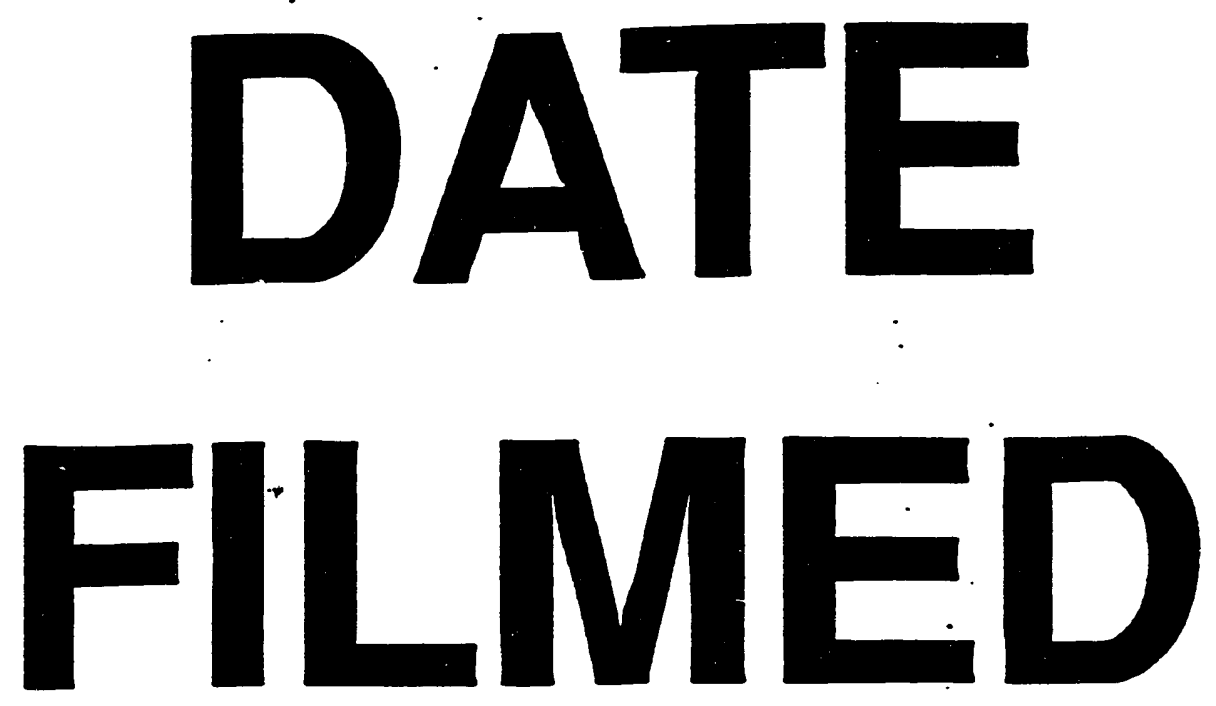

$1 / 10 / 94$
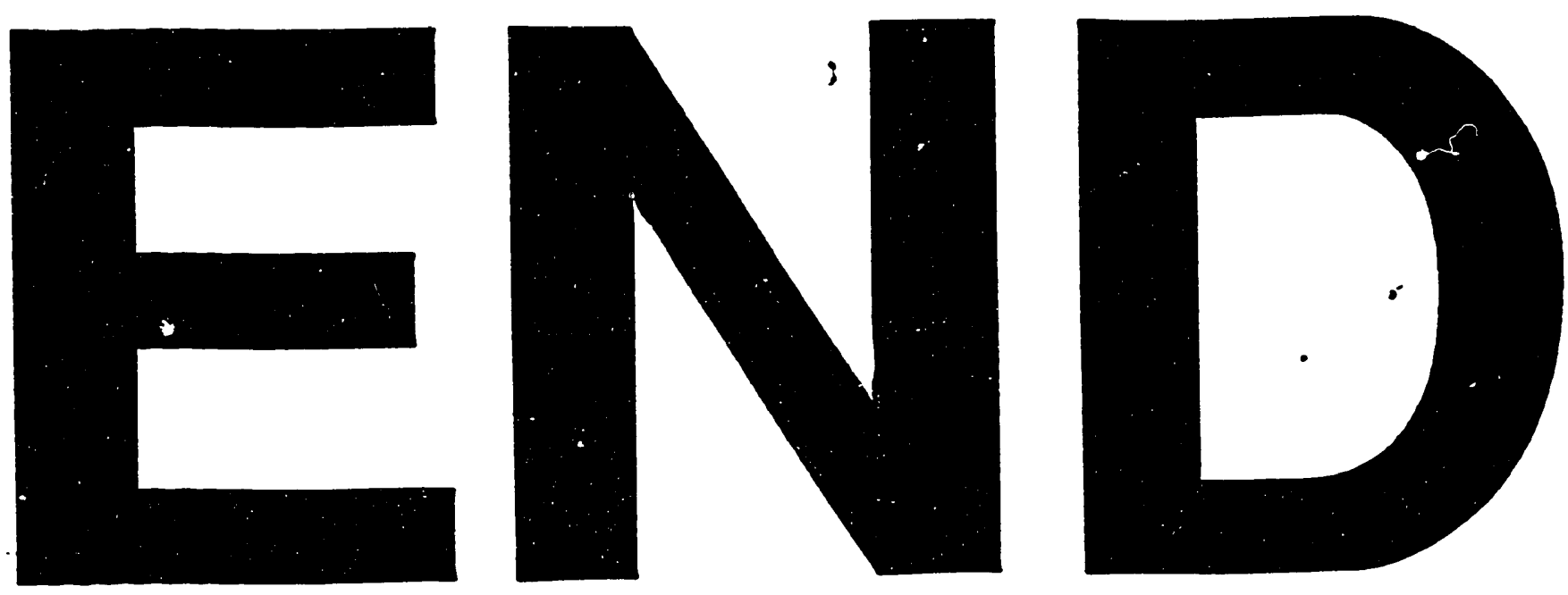
